\title{
КИРНИЦЬКИЙ ОЛЕГ,
} магістр політології, аспірант кафедри філософії Донецьького національного університету, м. Вінниця

\section{МОВА ЯК АУТОПОЕЗИСНИЙ ЕЛЕМЕНТ СОЦІАЛЬНОГО КОНСТРУЮВАННЯ}

У статті досліджено конструктивістські контексти феномену мови. У дослідженні автор акцентує увагу на аутопоезисній й віртуальній природі мови в просторі соціального. Особлива увага приділяється ролі мови у конструктивістських механізмах творення соціальної реальності сучасних суспільств. Розглядаються можливості мови щодо зміни конфігурацій соціального буття. Соціальна реальність у всій складності її розумінь постає як конструкт, утворений певним станом взаємозв'язків між найрізноманітнішими соціальними структурами і набуває чіткого віртуального "відбитку" в мові.

Ключові слова: мова; самовідтворення; віртуальність; соціальне конструювання; соціальна реальність; аутопоезис.

Постановка проблеми. Слово аутопоезис походить від грецьких слів autos - само, poiein - твір, побудова. Теорію аутопоезису вперше подано Ф. Варелою і У. Матураною. Трактування мови як аутопоезисного компонента, аналіз ії включеності в мережу соціальноконструктивних процесів дає великий змістовий матеріал для розуміння віртуальних механізмів соціального конструювання. Найбільш актуальною проблемою при дослідженні суспільства як унікального конструкту постала необхідність поєднати дуалізм суспільного (у вигляді колективно утворених соціальних дій, норм, правил співіснування, традицій) та індивідуального (у вигляді суб'єктивних почуттів, емоцій, переживань, рефрлексії). Дослідники поставили відповідь на це питання на одне з провідних місць від самого початку зародження знання про соціальне. Але найбільш вдалу й перспективну, на наш погляд, концепцію, яка до сьогодні лише посилює свої позиції, запропонували діячі лінгвістичного напрямку фрілософсського знання.

Аналіз досліджень і публікацій з проблеми. Біфуркаційною точкою оформлення цього наукового напрямку можна вважати 1916 рік та роботу Ф. де Сосюра "Курс загальної лінгвістики" [1]. У ній автор вперше позначив необхідність вивчення соціальної реальності у жорсткій зв'язці із лінгвістичними аспектами, тому що соціальна реальність у всій своїй складності постає як конструкт, створений саме конфігурацією взаємоз'язків між певною масою, критичним об'ємом найрізноманітніших соціальних структур, феноменів, груп індивідів, культур й набуває чіткого віртуального "відбитку" лише у вигляді мови. Ця логіка подібна до локківскої "tabula rasa" індивідуальної свідомості, але в масштабах цілісної соціальної системи. Саме мова в баченні Ф. де Сосюра постає "tabula rasa" для цілих суспільств, в якій постійно проходять процеси переписування, оновлення, перемішування, відмирання значень між старим та новим, що й робить її соціально динамічною, константною (у певні моменти) та замкненою системою. Для цього Ф. де Сосюр семантично виділяв розуміння мови як langue (спілкування взагалі) й мову як parole (мовлення, мовний акт), розділяючи таким чином соціальне та індивідуальне $[1$, с. 40]. Й тут мова набуває якості аутопоезисності - самовідтворюваності, самовиробниц- тва. Тобто постає організованістю, що породжує сама себе й із себе самої [2, с. 5-11]. Важливим постає факт, що ці висновки стали точкою зародження семіології, а мова - віртуальним референтом метаконструкту "соціальна реальність". Ф. де Сосюр перш за все хотів побачити, яке значення, трактування, зміст привносить слово у соціальну реальність, як існує механізм його прив'язки до матеріального. Й саме мова як "parole" вбачалася ним основою для існування знаків у феноменологічному їх баченні. Мова - це перш за все система загальноприйнятих знаків, значимостей, взаємозв'язків, відображених у мінімальному лінгвістичному еквіваленті - слові. Цим Ф. де Сосюр заклав розуміння мови як універсального віртуального інструменту саморегулювання сталості будь-якого соціального утворення.

Елементи тематики аутопоезису в соціально-філософській літературі простежуються в класичних роботах: Ф. де Сосюра [1], В. Гумбольдта [3], Е. Сепіра [4], Дж. Серла [5] та інш. Безпосередньо саму ідею аутопоезису вперше позначили в своїх роботах У. Матурана та Ф. Варела [2].

Метою цієї статті $є$ аналіз аутопоезисної функції мови у соціальному конструюванні.

Виклад основного матеріалу. Саме можливості мови щодо сигніфрікації, означання, еквівалентності щодо певного фрагменту (предмету, феномену тощо) соціальної реальності надають можливість індивіду опрацьовувати у власній свідомості цю соціальну реальність, утворюючи власне її розуміння. Мова є невід'ємною віртуально існуючою й нематеріальною складовою будь-якої соціальної структури, відтвореної сумою взаємодій та комунікації індивідів у їх повсякденній реальності. Вона оформлює майже весь спектр соціальних подій (у соціологічному їх баченні як анг. "events" наслідок, проява) бо, як зазначав В. Гумбольт, постає звичним елементом сталості людської духовної діяльності: "мовленнєва діяльність ("parole" у Сосюра) являє себе "поєднанням індивідуального сприйняття" індивіда. Саме в мові людини індивідуальна мова досягає своєї кінцевої визначеності" [3, с. 14]. Це розуміння найбільш наближене до позицій феноменології, бо у такому трактуванні мова постає ідеальним віртуальним інструментом для означання (сигніфікації) 
"безпередумовного досвіду свідомості, що пізнає" [3, с. 14]. Але тут і виникає казус, що потребує уваги до мови як феномену, який підтримує сталість соціального. Безпередумовний досвід пізнаючої свідомості вже не $є$ "безпередумовним". Бо для того, щоб його передати від однієї свідомості (індивіда), що пізнає, до іншої, потрібен віртуально існуючий посередник, яким виступає інструмент мови. Він завжди опосередковує наше існування й комунікацію в соціумі, а тому $є$ тотальним щодо буття. Таким чином мова набуває самовідтворюючої природи щодо суспільного.

Через феномен мови й кожне наше знання та розуміння соціального також набуває аутопоезисності: коли соціальне пояснюється через процеси, що відбуваються, відтворюються всередині самої організації соціального. До характерних властивостей мови як автопоезисного компоненту соціального конструювання слід віднести самовідтворення і безперервний саморозвиток. У все більш віртуалізованому соціальному світі саме ці характеристики стають засадничими. Безпосередньо надана у відчуттях соціальна реальність пояснюється й описується нами виключно сенсами, значеннями, цінностями, що оформлені мовою, яка також $є$ наскрізь соціальною за своєю природою. Але в цей самий час й кожен окремий елемент соціальної реальності існує завдяки мовній комунікації. На тлі цього твердження мова постає віртуально існуючим феноменом, який підтримує сам себе, будучи при цьому нерозривно пов'язаним з кордонами окремого соціуму. Мова може у такому контексті сприйматися як "методологічна оптика" процесів свідомості. Вона монопольно контролює й опосередковує осмислення людством надскладного конструкту світу соціального буття XXI століття, при цьому паралельно конструюючи цей світ завдяки повному контролю комунікації всередині нього.

Кожна мова - це аутопоезисна, замкнена "сама-насобі" система сигніфікації соціальних структур та мереж зв'язків між ними. За такої розширеної сосюрівської моделі розуміння мови, вона як одночасно формує структурні елементи соціального, так і заздалегідь задає їх можливі кордони розумінь для нас. Ван Дейк називав мову силою, яка конституює суспільство. В інформаційному суспільстві, коли ставиться питання про структури і способи конструювання смислів, роль мови виходить на перший план.

Слід констатувати той френоменологічний фракт, що будь-який досвід свідомості, що пізнає, є абсолютно унікальним. Тому мова виступає в ролі певної "оптики", що дозволяє виражати індивідуальне розуміння соціального світу кожного члена суспільства навколо нас. "Різні мови не є різними позначеннями одного й того $ж$ предмету, а різними його відчуттями", тому слово, за Гумбольдтом, $є$ віртуальним відбитком предмету як самого по собі, й означенням його чуттєвого образу, сконструйованого сумою індивідуалізованих розумінь [3, с.11].

Можливість пізнання нашою свідомістю предмету, явища, феномену як "такого-як-він-є" завжди опосередковується мовою, а тому й є неможливим його кантівське "чисте" пізнання. Тут мова зі своєю аутопоезисною природою виходить за рамки "суб'єкта-об'єкта" пізнання. Мова виступає регіоном трансцендентального, тим, що опосередковує "суб'єкт-об'єктне" розуміння буття. Якщо матеріальна реальність, що оточує нас, має за основний інструмент впливу на свідомість безпосередні фізичні відчуття (матеріальна даність має спротив щодо нашого тіла), то основним інструментом підтримання суспільством власних утворень $€$ мова. Остання існує й твориться віртуально, колективно й мак- симально відповідно до соціально-побутових реалій суспільства "тут-і-зараз". Мова закладає основу комунікаційного процесу між індивідами, бо дозволяє віртуально виводити різноманітні елементи індивідуального досвіду на надіндивідуальний рівень й представляє елементи такого досвіду у вигляді окремих еквівалентних до нього частин "артикульованого звуку" - слів, понять, категорій, що $€$ основними носіями змісту та значення. Це твердження згодом було розвинуто в теорії Сепіра-Уорфа про співвіднесеність структури мови та світосприйняття індивідів [4, с. 11-12].

Переводячи це твердження у практичну площину, слід зазначити, що наше повсякденне соціальне буття, в яке людська свідомість вносить осмисленість й значення, без мови мало б змісту не більше, ніж повсякденність тварини - про що стверджує Д. Серль [5, с. 3-7].

Тобто, мова виступає елементом, що $є$ наскрізь соціальним для будь-якого соціального утворення й, особливо, для окремого соціального конструкту в мовних кордонах якого ці структури склалися: поселення, держави, регіону, цивілізації.

Таким чином, у соціально-фрілософрському знанні роль мови починає поступовий вихід з рамок лінгвістичного бачення. Відхід від традиційного розуміння мови задає аналітична фрілософія, що бачить ії̈ як аутопоезисний елемент конструювання соціальних взаємодій, а не як самостійну й відсторонену систему сигніфікацій. Якщо раніше стверджувалося, що ми соціальні тому, що мислимо, наділяючи слова значенням (meaning), то аналітична фрілософрія (лінгвістичний ії напрям) доводить, що мова як віртуальна система значень забезпечена у своєму існуванні саме елементами соціальної реальності. Цей фракт дозволив Л. Вітгенштейну говорити, що не існує й не може бути оформлена "особиста мова" ("private language"). Бо тоді ми не змогли б відрізняти, правильно ми використовуємо мову, чи ні. А це привело його до висновку, що мова визначається не значенням самим по собі, а загальним практичним використанням кожної її категорії. Слово (поняття) докорінно залежить від його соціального вживання, а не від того, що воно позначає. Мова $є$ формою буття, "домом буття" за М. Гайдеґером, саме через еквівалентність, віртуальну (як ідеально-потенційну) співвіднесеність до соціального. Цей фракт покладено в основу, наприклад, фрілософського напрямку структурної семантики, де значення категорії не може бути описаним без звернення до лексичних одиниць одного семантичного поля, й бачення значення окремого слова як "рівноваги" з-поміж іншими словами одного семантичного поля. У філософії склалася ситуація, коли мова виявляє себе як інструмент структурації дійсності [6].

Такий доробок ідей Гумбольдта [7, с. 300-302] на тлі феноменологічного повороту філософської думки дозволяє дослідникам соціально-філософської галузі вивчати феномен суспільства як системної єдності елементів, що відображені у мові та окремих аспектах їі конструкції: фонетичних, синтаксичних й, що найгловніше, семантичних. Феномен мови відбиває в собі саму суть елементів соціального (його структур), що, взаємодіючи, утворюють кожен соціум як такий: духовних складових націй, вкорінених звичаїв та вірувань, актуальних в певну епоху, моделей мислення, явищ в економіці й т.i. [8, c. 195].

Збірка соціального у єдине функціональне ціле проходить, в тому числі, у рамках комунікації в повсякденному бутті. Повсякденність подає унікальний досвід кожного індивіда, вкладений у межі процесу конструювання соціальних структур й виражений через феномен мови. Звісно, останній постає частиною семіотич- 
ного погляду на світ соціального, бо паралельно з ним існує широкий ряд інших феноменів, що утворюють замкнені системи значимостей ("valeurs" у Сосюра) у соціальних інтеракціях: невербальне (жести), позасвідомі аспекти індивідуального, алгоритмічне, традиційне, мистецтво, символіка і т.д. [9, с. 147-158]. Але сосюрівське мовлення ("parole") завжди має "віртуальну" перевагу. Його можна накласти (позначити ним) на кожну утворену структуру, що існує в рамках певної соціальної системи, або через нього описувати інші "значимі системи значимостей" семіології. [110, с.74]. Тому ключовим для аналізу розуміння-конструювання соціальної реальності є "мовленнєвий акт". Він $є$ "відбитком", відображенням, копією індивідуального досвіду свідомості, їі поглядів, установок, несвідомих аспектів функціонування.

Вкрай вдало аутопоезисну та докорінно залежну від соціального буття природу мови розвинув М. Фуко у своїй відомій праці "Слова та речі", виділяючи як ключові елементи процесу конструювання соціального мову та працю [10, с. 40-43]. Згодом він за допомогою дослідження мовного аспекту перейшов до розуміння механізмів конструювання за допомогою знання тих взаємозв'язків між елементами соціального, що здійснюються у віртуальному "полі дискурсу", який "оживає" й приводиться до руху виключно завдяки нематеріальній природі мові.

Лише у XX столітті ряд лінгвістів й соціальних філософів наддетально переглянули розуміння феномену мови: Ф. де Сосюр, Л. Вітгенштейн, Д. Серл та ін. До них лише Гумбольдт як один з перших метафрізиків-лінгвістів осмислював питання мови через буття, що задавало фундаментальність мові, й тому феномен мови можна розуміти як "не лише унікальний дар людства, але і його сутнісну характеристику" [11, с. 7]. На сучасному етапі вчені мають надвисоку кількість емпіричного матеріалу, в якому позначають своєрідність кожної мови, особливість впливу мови на світосприйняття. Вони вивели розуміння "мовної особистості", "мовного акту", "аперцептивного фону", "дискурсності" і т.д. Але жодне з цих досліджень не може дати повноцінну відповідь на свої питання без розуміння аутопоезисних й віртуальних основ мови. Будь-який сучасний напрямок фрілософії, що торкається дослідження соціального в тому чи іншому форматі (соціальна, аналітична, когнітивна філософрія тощо), першочерговою своєю метою ставить визначення причини, місця, ролі, значення мови в екзистенційно-онтологічній тріаді "буття - мова - індивід". Не можна казати, що ми "відкриваємо нове в мові", бо це неправильне трактування. Скоріше, пізнаючи мову, ми пізнаємо саме буття, бо, як зазначав Гайдеґер: "Мова говорить. Людина говорить лише настільки, наскільки відповідає мові. Все написане спрямоване лише на те, щоб навчити жити у говорі мови" [12, с. 20]. Тому можно зробити висновок, що людина не стільки висказується, скільки оформлює "говір буття" в собі та через себе.

Можна стверджувати: мова у її відірваному від соціального розумінні має мізерні здатності до конструювання, моделювання, модифрікації соціальної реальності і $є$ лише віртуальним відображенням стану соціальних структур соціуму. Набуває мова можливостей до переконструювання нашого буття лише в тому разі, коли забезпечується її аутопоезисна щодо процесів соціального природа: вона стає мовленням як тотальним за поширеністю процесом комунікації, мовним актом Д. Серла. На це вказував і М. Гайдеґер, бо вважав, що лише саме так можна, як "мислити мову", так й "мислити саме буття": "це означає вступити у мовлення в бутті для того, щоб існувати при мові, тобто бути під її впливом... Лише так ми досягнемо сфери, всередині якої, вдало чи ні, мова проговорить нам свою сутність. Мову ми поступаємо мовленню. Ми не можемо обґрунтувати мову чимсь іншим, аніж нею самою, як не можемо пояснити інше без мови" [12, с. 3].

\section{Висновки}

Будь-який з філософських напрямків не може не залежати від аксіоматичного допущення, що мова як відтворює наш світ соціального, так і докорінно залежить від нього. Це відбувається завдяки саме віртуальній природі її існування, незалежності від матеріальної складової, а лише від диспозицій й розумінь утворених колективно-соціально, що й "віддає" індивідам світ буття для подальшого розуміння, надаючи ӥй статусу "регіону трансцендентального". Феномен мови віртуально (у вигляді слів, категорій, стійких мовленнєвих оборотів) являє для нашої свідомості явища та події нашої реальності, беручи таким чином соціальне "в себе", взаємовідтворюючись, постаючи нероздільним з ним у єдиному цілому.

Поліфонічність відкритого мережевого простору робить значущим фрактор мовного і комунікативного статусу учасників соціальної взаємодії. Тут головною функцією мови стає не доставка інформації, а взаємна орієнтація учасників комунікації всередині узгодженої області. Комунікація стає способом взаємної орієнтації ії учасників безпосередньо відносно один одного і опосередковано щодо будь-якої предметної області, речі.

Концепція мови як аутопоезисного елемента соціального конструювання $€$ важливою частиною нашої дослідницької стратегії. Аутопоезисні характеристики мови полягають у тому, що їй надається властивість оператора, що впливає на смислове поле соціального і має цілий спектр власних значень. Мовні компоненти беруть участь у формуванні простору соціального життя в бажаному напрямку. У дискурсивному просторі нових соціальних смислів мова не тільки відображає і описує вже сформовану реальність, але інтерпретує, коригує і трансформує ії.

\section{ЛПТРАТУРА}

1. Соссюр Ф. Заметки по общей лингвистике / Ф. Соссюр. - М. : Прогресc, 1990. - 280 c.

2. Матурана У. Древо познания / У. Матурана, Ф. Варела. - М. : Древо познания, 2001. - 224 с.

3. Гумбольдт В. Избранные труды по языкознанию / В. фон Гумбольдт. - М. : Прогресс, 2000. - 400 с.

4. Sapir E. An Introduction to the Study of Speech / E. Sapir. New York : Dover Publications, 2000. - 204 p.

5. Searle J. R. Speech Acts: An Essay in the Philosophy of Language / J. R. Searle. - Cambridge : Cambridge University Press, 1970. - 203 p.

6. Вайсенберг Л. Родной язык и формирование духа / Л. Вайсенберг. - М. : УРСС Эдиториал, 2004. - 232 с.

7. Гумбольдт В. О мышлении и речи // Гумбольдт В. Избранные труды по языкознанию / В. фон Гумбольдт. - М. : Прогресс, 1984. - С. 301-302.

8. Гуревич А. Я. Исторический синтез и школа "Анналов" / А. Я. Гуревич. - М. : Индрик, 1993. - 328 с.

9. Лотман Ю. Семиосфера: Культура и взрыв Внутри мыслящих миров / Ю. Лотман. - СПб. : Искусство - СПб., 2000. - 704 c.

10. Фуко М. Слова и вещи. Археология гуманитарных наук / М. Фуко. - СПб. : А-cad, 1994. - 408 с.

11. Stubb E. Wilhelm Von Humboldt's Philosophy of Language, Its Sources and Influence / Elsina Stubb. - Lewiston, N.Y. : Edwin Mellen Press, 2002. - 332 p. - (Studies in Linguistics and Semiotics, V. 9).

12. Хайдеггер М. Язык / М. Хайдеггер. - М. : Эйдос, 1991. - 
Кирницкий Олег, магистр политологии, аспирант кафедры философии Донеикого национального университета, г. Виннииа

\section{ЯЗЫК КАК АУТОПОЭЗИСНЫЙ ЭЛЕМЕНТ СОЦИАЛЬНОГО КОНСТРУИРОВАНИЯ}

В статье изучены конструктивистские контексты феномена языка. В исследовании автор акцентирует внимание на аутопоэзисной и виртуальной природе языка внутри социального. Особое внимание уделяется роли языка в социально-конструктивистских механизмах создания социальной реальности обществ двадцать первого века. В работе рассматриваются возможности языка по изменению конфигураций социального бытия. Социальная реальность во всей сложности ее пониманий трактуется как конструкт, созданный состоянием взаимосвязей между определенной массой, критическим объемом самых различных социальных структур и понимается нами только в четкого виртуального "отпечатка" - языка.

Ключевые слова: язык; самовоспроизведение; виртуальность; социальное конструирование; социальная реальность; аутопоэзис.

Kirnitikiy Oleg,

Master of political science, Postgraduate Department of Philosophy

Donetsk National University, Vinnytsia

\section{LANGUAGE AS AUTOPOIESIS ELEMENT OF SOCIAL CONSTRUCTION}

The article explores the constructivist contexts of the phenomenon of language. In the study, the author focuses on the autopoiesis and virtual nature of the language within the social. Particular attention is paid to the role of language in the social constructivist mechanisms of creating the social reality of the societies of the twenty-first century. The paper examines the possibilities of the language in changing the configurations of social life.

Social reality in all its complexity appears as a construct is created as interferences between some weight, the critical volume of a variety of social structures and a distinct virtual "fingerprint" - language. Therefore, it appears, exposing its metaphorical reduction, some "optics" that allows you to see the social world around us.

To understand the social world through language as possible transcendental region that mediates any social cognition. It optics, allowing you to see the object of knowledge required for the researcher "angle of view". Thus, the article language vision of the role gradually out of linguistic vision frames only. Check out the traditional understanding of the language sets the analytic philosophy that sees it as a design autopoiezis element social interactions and not as aloof and independent system of values. At the same time it acts as a medium so that constructs a social world through social researchers very difficult to investigate a separate phenomenon of "a selfcontinue", taken separately, out of context, executes all social structures into a single space semiotic meanings.

Autopoiesis concept of language as an element of social construction is an important part of our research strategy. Autopoiesis characteristics of speech lies in the fact that it provided service property that affects the semantic field of social and has a range of eigenvalues. Treatment language as autopoiesis component analysis of its involvement in a network of social and structural processes makes great material for a meaningful understanding of the mechanisms of virtual social construction. Typical properties of language as a social construction autopoiesis component should include continuous self-development and self-renewal. In an increasingly virtualized world, these social characteristics are fundamental

Keywords: language; reproduction; virtual; social construction; social reality; autopoesis.

\section{REFERENCES}

1. Saussure, F. (1990), Notes on general linguistics [translat.], Progress Publishing, Moscow, 280 p. (rus).

2. Maturana, U. \& Varela, F. (2001), The Tree of Knowledge, The Tree of Knowledge Publishing, Moscow, 224 p. (rus).

3. Humboldt, V. (2000), Selected Works on Linguistics, Progress Publishing, Moscow, 400 p. (rus).

4. Sapir, E. (2000), An Introduction to the Study of Speech, Dover Publications, New York, 204 p. (eng).

5. Searle, J. R. (1970), Speech Acts: An Essay in the Philosophy of Language, Cambridge University Press, Cambridge, 203 p. (eng).

6. Weissenberg, L. (2004), Mother tongue and spirit formation [translat.] URSS Editorial, Moscow, 232 p. (rus).

7. Humboldt, W. (1984), On On Thinking and Speaking, in: Selected works on linguistics [translat.], Progress Publishing, Moscow, pp. 301-302 (rus).

8. Gurevich, A. Ya. (1993), Historical synthesis and school "Annals", Indrik Publishing, Moscow, 328 p. (rus).

9. Lotman, Yu. (2000), The Semiosphere: Culture and Explosion Inside the Thinking Worlds, Art - St. Petersburg Publishing, St. Petersburg, 704 p. (rus).

10. Foucault, M. (1994), The Order of Things: An Archaeology of the Human Sciences [translat.], A-cad Publishing, St. Petersburg, 408 p. (rus).

11. Stubb, Elsina (2002), Wilhelm Von Humboldt's Philosophy of Language, Its Sources and Influence, Edwin Mellen Press, Lewiston, N.Y, 332 p. (Studies in Linguistics and Semiotics, V. 9).

12. Heidegger, M. (1991), Language [translat.], Eidos Publishing, Moscow, 22 p. (rus).

(c) Кирницький Олег

Надійшла до редакції 17.04.2016

СХІД № 2 (142) березень-квітень 2016 р. 